Jurnal Natur Indonesia 12(2), April 2010: 93-101

ISSN 1410-9379, Keputusan Akreditasi No 65a/DIKTI/Kep./2008

\title{
Improvement of Selected Induction Culture Media on Callus Induction in Anther Culture of Anthurium and a Histological Study on its Callus Formation
}

\author{
Budi Winarto ${ }^{1 *}$, Nurhayati Ansori Mattjik²), Agus Purwito's), and Budi Marwoto1) \\ 1)Indonesian Ornamental Crops Research Institute, Jln. Raya Ciherang, Pacet-Cianjur 43253 West Java \\ ${ }^{2)}$ Agronomy and Horticulture Department, Faculty of Agriculture, Bogor Agriculture Institute. \\ Jln. Meranti No. 1 Darmaga, Bogor, West Java. \\ Diterima 11-05-2009 Disetujui 05-11-2009
}

\begin{abstract}
Improvement of selected induction culture media on callus induction in anther culture of anthurium and a histological study on its callus formation were studied at the tissue culture laboratory of the Indonesian Ornamental Crops Research Institute from February to October 2008. The objectives of the study were to optimize selected media for callus formation, reveal cell origin of callus derived from anther culture and shoot formation process. Selected media improved in the study were 1) MMS-TBN containing 0,5 mg// TDZ, 1,0 mg/l BAP and 0,01 mg/l NAA (Winarto medium, WM) and 2) MMS III supplemented with $1,5 \mathrm{mg} / \mathrm{l} \mathrm{TDZ,} \mathrm{0,75} \mathrm{mg/l} \mathrm{BAP} \mathrm{and} \mathrm{0,02} \mathrm{mg/l} \mathrm{NAA} \mathrm{(Winarto} \mathrm{and}$ Rachmawati medium, WRM). Improvement treatments were carried out by omission and application of 2,4-D in 0.5 $\mathrm{mg} / \mathrm{l}$ and reduction of medium strength of full, half, quarter, one eighth, one sixteenth, and zero strength. A factorial experiment was arranged using a randomized complete block design with four replications. Results of this study indicated that the highest callus induction was clearly established in WRM. The medium stimulated potential growth of anther (PGA) up to $81 \%$ with $49 \%$ of percentage of anther regeneration (PAR) and 2.7 number of callus formed per replication (NCF). Significant improvement in callus formation was also recorded by reduction of medium strength of WRM to one eighth compared to others. The reduction induced PGA up to $58 \%$ with $29 \%$ of PAR and 1.8 NCF. From histological studies it was well recognized that regenerated callus on half anthers cultured was originated from middle layer cells of anther wall. The morphogenic response of anther wall cells caused primarily on no androgenesis effect in microspore cells.
\end{abstract}

Keywords: anthurium, callus of anther, histology, Media improvement

\section{INTRODUCTION}

Application of anther culture and/or microspore culture in ornamental crops till now is still limited. The technique was reported in several plants such as on lily (van den Bulk et al., 1992; Han et al., 1997), tulip (Tanaka and Ito, 1981 \& 1982; van den Bulk et al., 1994), sunflower (Saji \& Sujatha 1998), petunia (Mohan-Jain \& Bhalla-Sharin 1996), Camelia japonica (Pedroso \& Pais 1996). While in Araceae, especially in anthurium, its application was very limited. In Araceae, double haploid plant production was tried in Spatiphyllum via ovule culture (Eeckhaut et al., 2001), but number of double haploid plant produced was very low.

Winarto and co-workers tried and initiated experiments in anther culture of anthurium in 2003. Two important points determined from the previous results were 1) two different calluses were regenerated from anther culture and 2) Modified Murashige and Miller

\footnotetext{
*Telp: +62819096522440

Email: ya_nuriwinarto@yahoo.com
}

Syngonium (MMS) containing $1.5 \mathrm{mg} / \mathrm{l} \mathrm{TDZ}, 0.75 \mathrm{mg} / \mathrm{l}$ BAP and $0.02 \mathrm{mg} / \mathrm{l}$ NAA (Winarto \& Rachmawati medium, WRM) was the most potential medium to induce callus and its regeneration (Rachmawati 2005; Winarto \& Rachmawati 2007). In a comparative study it was also found that MMS supplemented with $0.5 \mathrm{mg} / \mathrm{l} \mathrm{TDZ}, 1.0 \mathrm{mg} / \mathrm{lBAP}$ and $0.01 \mathrm{mg} / \mathrm{I} \mathrm{NAA}$ (Winarto medium, WM) was another potential medium in anther culture of anthurium (Winarto et al., 2009).

Two different calluses derived from anther that a part of them often showed different colors in their performance (green and yellow in Tropical and Amigo cultivars; red-purple and yellow in Carnaval cultivar) and growth types (slow and fast) interested to be studied in detail via their histology. From the histological study it was expected that callus origin could be clearly known. In the first time it was hypothesized that the slow growth callus was initiated from microspore cells and the faster one was derived from anther wall and/or 
connective tissue cells. Important role of the study in in vitro cultures was generally carried out to support and strengthen research results. The study was applied in anthers of Vitis rupcstris (Altamura et al., 1992), in androgenesis of rice (Oryza sativa L.) (Nakano \& Maeda, 1989; Mandal \& Gupta, 1996), in callogenesis and organogenesis of Curcuma zedoaria Roscoe (Mello et al., 2001), in petiole derived callus of Amorphophallus rivieri Durieu (Hu et al., 2005).

Improvement of induction culture medium in callus initiation and formation via application of 2,4-d and/or increasing its concentration was actually contributed in increasing morphogenic response of the anther walls and connective tissues to divide actively and produce callus as stated by Rodrigues et al., (2004) in soybean anther culture. Enhancing callus initiation due to 2,4-D treatment was also recorded by Thangene et al., (1994) in anther culture of sunflower, Arzate-Fernandez et al., (1997) in lily, Oggema et al., (2007) in sweet potato, (Kumar \& Kanwar 2007) in Gerbera jamesonii. Strengthening medium capacity in callus induction was also recorded successfully by reduction of the medium strength to be half, quarter, or others as reported by Hoque and Arima (2002) in callus induction of water chestnut (Trapa Japonica Flerov), Chen et al., (2005) in Bupleurum kaoi Liu, Jabeen et al., (2006) in Aconitum heterophyllum, (Wang \& Bao 2007) in Viola wittrockiana. Furthermore application of 2,4-D and reduction of medium strength in anthurium anther selected medium expected could improve medium capacity in stimulating high response of the anthers cultured for producing callus.

The objectives of the present investigation were to improve selected induction culture medium in anther culture of anthurium by 2,4-D application and reduction its strength on callus formation and to reveal from which cell and/or tissue actually the regenerated calluses on anther culture derived.

\section{MATERIALS AND METHODS}

Preparation of aseptic plant materials. This research was conducted at Tissue Culture Laboratory of Indonesia Ornamental Crops research Institute from February to October 2008. Anthurium andreanum Linden ex André c.v. Tropical used in the experiments was grown in plastic bags $(30 \mathrm{~cm}$ in diameter) in a mixture of rice-hush + bamboo moss + cicas $(1: 1: 1, \mathrm{v} / \mathrm{v} / \mathrm{v})$ as a potted medium. The plants were placed in the glass house and maintained optimally via fertilization (application of $1 \mathrm{gr} \mathrm{NPK}$ (15:15:15) per plant monthly and using $1.5 \mathrm{ml} / \mathrm{l}$ of Grow-more once two weeks) and watering them. Spadixes with $50 \%$ of its pistil in receptive condition were harvested from the plants.

In the first step, spadixes were placed under tap water for 30-60 minutes to reduce high contamination, followed by immersing in pesticide solution ( $1 \%$ of benomil and bactomycin) for 30 minutes and then rinsed by distillated water for 5-6 times with 5 minutes each. After first step sterilization, the spadixes were brought into laminar air flow cabinet for next sterilization. Explants were soaked in $2 \%$ of sodium hypochlorite ( $\mathrm{NaOCl}$ ) plus 5 drops of Tween 20 for 5 minutes, $1 \%$ of $\mathrm{NaOCl}$ added by 5 drops of Tween 20 for 10 minutes, followed by rinsing in distillated sterile water for 5-6 times with 5 minutes each. The sterile spadixes were used in all experiments.

Improvement of anthurium anther selected media via addition of 2,4-D. Sterile spadix was put in sterile petridish, cut the transition area and used for anther isolation. Petals were then removed carefully and anthers were isolated using tissue culture blade. Top part of anther (halve anther) without filament was isolated and cultured in the culture medium tested. All isolation activities (anther isolation steps) are under stereo microscope.

Selected media improved in the study were medium 1 is MMS-TBN containing $0.5 \mathrm{mg} / \mathrm{l} \mathrm{TDZ}, 1.0 \mathrm{mg} / \mathrm{l} \mathrm{BAP}$ and $0.01 \mathrm{mg} / \mathrm{INAA}$ (Winarto medium, WM) and medium 2 is MMS III supplemented with $1.5 \mathrm{mg} / \mathrm{I} \mathrm{TDZ \text {, }}$ $0.75 \mathrm{mg} / \mathrm{l} \mathrm{BAP}$ and $0.02 \mathrm{mg} / \mathrm{l}$ NAA (Winarto \& Rachmawati medium, WRM). Improvement of medium in callus induction was carried out by addition of 2,4-D in $0.5 \mathrm{mg} / \mathrm{l}$. Media tested in the experiment were 1) MMS-TBN without 2,4-D (WM), 2) MMS III without 2,4-D (WRM), 3) MMS-TBN added by $0.5 \mathrm{mg} / \mathrm{l} 2,4-\mathrm{D}$ (WM-D) and 4) MMS III supplemented with $0,5 \mathrm{mg} / \mathrm{l}$ 2,4-D (WRM-D). All semi solid media contained $30 \mathrm{~g} / \mathrm{l}$ sucrose and were adjusted at $\mathrm{pH} 5.8$ before thier sterilization in $121^{\circ} \mathrm{C}, 15 \mathrm{kPa}$ for 20 minutes.

The experiment was arranged using a randomized completely design with four replications. Each treatment consisted of 3 bottles and each bottle contained 6 anthers. All cultures were incubated in the dark condition for \pm 2 months; afterward the cultures 
were put under fluorescent lamp $\left(13 \mu \mathrm{mol} . \mathrm{m}^{-2} . \mathrm{s}^{-1}\right)$ for $12 \mathrm{~h}$ photoperiod until callus formed. Parameters observed in all experiments were 1) potential growth of anther (PGA, \%), 2) percentage of anther regeneration (PAR, \%), and 3) number of callus formed per replication (NCF). The first parameter was recorded one month after culture initiation; second one was noted 2.0 months after culture initiation; and third one was collected 3.0 months after culture initiation. Quantitative data were analyzed by analysis of variance (ANOVA) using SAS program Release for Windows 6.12. In cases where significant differences were obtained $(p=0.05)$, Duncan's Multiple Range Test (DMRT) was used for comparison between means.

Improvement of anthurium anther selected media via medium strength reduction. Anther isolation steps were carried out as previously described in experiment 1 mentioned above. Selected media improved in the study were 1) WM and 2) WRM. The media were improved by reducing content of mineral salts of maco, micro and vitamin elemens of full, half, quarter, one eighth, one sixteenth, and zero strength. The zero strength was anly contained $2.0 \mathrm{~g} / \mathrm{l}$ gelrite. The factorial experiment was arranged using a randomized complete block design with four replications. Each treatment consisted of 3 bottles and each bottle contained 6 anthers. Culture condition, observation and quantitative data analysis were conducted as previously described in experiment 1 . All media contained $30 \mathrm{~g} / \mathrm{l}$ sucrose and adjusted to $\mathrm{pH} 5.8$ prior to sterilization in $121^{\circ} \mathrm{C}, 15 \mathrm{kPa}$ for 20 minutes.

Histological study of callus formation. The histological study was carried out to recognize the original cells and/or tissues that produced callus derived from anthers. Callus explants were sampled at 0, 1, 2, and shoot initiation stage. The specimens were then fixed in the FAA solution (formalin: glacial acetic acid: $50 \%$ ethanol, 5:5:90 (v/v/v)) for $48 \mathrm{~h}$ and dehydrated in ethanol series $(30,50,75,95,100 \%(v / v))$ twice for 30 minute in each step. After dehydration the explants were immersed in xyline: paraffin in different ratios $(75: 25$, $50: 50,25: 75,0: 100)$ for an hour per ratio and in the final level explants were soaked in $100 \%$ paraffin for one night. In the next step samples were embedded with paraffin. Serial sections $(10-15 \mu \mathrm{m})$ were made with a rotary microtome model 820 Spencer and peaces of specimen sections were mounted with $10 \%$ of albumin-glycerin on objective glass. The specimens were double stained with $1 \%$ acid-fuchsin and $0.05 \%$ toluidine blue or safranin and fast green. Finally, the specimens were mounted with DPX mountant. The slides were then observed under the microscope and photographed.

\section{RESULTS AND DISCUSSION}

Improvement of anthurium anther selected media via addition of 2,4-D. Callus formation in anther anthurium was initiated 1.0-1.5 months after culture initiation. The initiated callus continued to grow in different shapes and sizes. Number of callus formed varied from 1-6 calluses per replication. A part of callus derived from anthers turned to brown and died. Anther and callus browning in anther culture of anthurium were caused by anther and callus slicing as reported in Pistachia vera (Ahmad 1993). Explant wounding induced stress and causes an increase in phenylalanine ammonia lyase (PAL) activity. High activity of PAL enhanced phenylpropanoid production that lead to explant browning (Tabiyeh et al., 2005). Another study reveals that the explant slicing led to cell damage and followed by sub-cellular material mixing from cytoplasm and vacuole (Laukkanen et al., 1999). Just after the occurence, phenolic compounds were oxidized by polyphenol oxidase enzyme to produce quinone compounds and polimer complex due to the existence of $\mathrm{O}_{2}$ (Marshall et al., 2000). The compounds were toxic and caused browning and death of explant (Stom et al., 2006; Ozygit et al., 2007).

Improvement of two selected media with 2,4-D, in fact, gave different effects on callus induction. In WRM, supplementation of 2,4-D in the medium reduced potential growth of anther down to $59 \%$ with $34 \%$ anther regeneration and 1.8 calluses formed per replication. While in WM, addition of 2,4-D $(0.5 \mathrm{mg} / \mathrm{l})$ increased average value of all parameters observed (Table 1 ). Based on the highest average of data recorded it was clearly known that WRM was the most suitable induction culture medium in callus formation of anthurium anthers. The medium exhibited the highest results and significantly different compared to other media.

Existence of 2,4-D in anther culture of anthurium clearly gave two different effects in two selected media tested i.e. strengthening and weakening effect of them. 
Table 1. Effect of 2,4-D supplementation in selected-media on callus induction in anther culture of anthurium

\begin{tabular}{lcccc}
\hline Selected Media & $2,4-\mathrm{D}\left(\mathrm{mg} . \mathrm{I}^{-1}\right)$ & $\begin{array}{c}\text { Potential growth of } \\
\text { anther }(\%)\end{array}$ & $\begin{array}{c}\text { Percentage of anther } \\
\text { regeneration }(\%)\end{array}$ & Number of callus formed \\
\hline MMS-TBN & 0 & $45.0 \mathrm{c}$ & $32.5 \mathrm{~b}$ & $1.8 \mathrm{a}$ \\
MMS-III & 0 & $80.8 \mathrm{a}$ & $48.6 \mathrm{a}$ & $2.7 \mathrm{a}$ \\
MMS-TBN & 0.5 & $63.8 \mathrm{~b}$ & $42.7 \mathrm{ab}$ & $2.4 \mathrm{a}$ \\
MMS-III & 0.5 & $58.5 \mathrm{~b}$ & $33.6 \mathrm{~b}$ & $1.8 \mathrm{a}$ \\
Coefficient variation & & 13.57 & 11.67 & 11.18 \\
\hline
\end{tabular}

a,b,c Means followed by the same letter in the same column are not significant different based on Duncan Multiple Range Test (DMRT, $p=0.05$ ).

Table 2. Effect of selected-induction culture media on callus formation in anther culture of anthurium

\begin{tabular}{lcccc}
\hline Selected Media & $2,4-\mathrm{D}\left(\mathrm{mg}^{-\mathrm{I}^{-1}}\right)$ & $\begin{array}{c}\text { Potential growth of } \\
\text { anther }(\%)\end{array}$ & $\begin{array}{c}\text { Percentage of anther } \\
\text { regeneration }(\%)\end{array}$ & Number of callus formed \\
\hline WRM & 0 & $48.3 \mathrm{a}$ & $18.8 \mathrm{a}$ & $1.2 \mathrm{a}$ \\
WM-D & 0.5 & $46.2 \mathrm{a}$ & $11.1 \mathrm{~b}$ & $0.7 \mathrm{~b}$ \\
Coefficient variation & & 10.89 & 20.67 & 19.43
\end{tabular}

a,b Means followed by the same letter in the same column are not significant different based on Duncan Multiple Range Test (DMRT, $p=0.05$ ).

The effect was probably caused by different concentrations of all medium components as reported by Winarto et al., (2009). Increasing $\mathrm{NH}_{4} \mathrm{NO}_{3}$ concentration from $500 \mathrm{mg} / \mathrm{l}$ to $750 \mathrm{mg} / \mathrm{l}$ and $\mathrm{KNO}_{3}$ from $1250 \mathrm{mg} / \mathrm{l}$ to $1750 \mathrm{mg} / \mathrm{l}$, enhancing myo-inositol from $110 \mathrm{mg} / \mathrm{l}$ to $125 \mathrm{mg} / \mathrm{l}$ and thiamine-HCl from $0.5 \mathrm{mg} / \mathrm{l}$ to $0.55 \mathrm{mg} / \mathrm{l}$ in WM to WRM improved medium capacity in inducing regenerative response of anther explant and role of the components in stimulating regenerative capacity was also stated by George (1993). Therefore addition of 2,4-D in the medium caused reduction in callus formation potential (weakening effect). With $1.5 \mathrm{mg} / \mathrm{ITDZ}, 0.75 \mathrm{mg} / \mathrm{I} \mathrm{NAA}$ and $0.02 \mathrm{mg} / \mathrm{l} \mathrm{NAA}$ without 2,4-D, WRM was to be the most suitable medium for anther culture of the plant. In another study reported that the existence of 2,4-D in the medium reduced cell viability in Doritaenopsis (Mishiba et al., 2001), caused microspore plasmolysis and did not improve androgenesis (Rodrigues et al., 2004).

Strengthening effect of 2,4-D supplementation in the medium was recorded in WM. The existence of the hormone stimulated callus induction capacity of the medium. Lower regenerative medium component and hormone concentration were improved by the application of the hormone. The effective effect of 2,4-D application at $0.5 \mathrm{mg} / \mathrm{l}$ in MS medium for callus induction was also recorded by Oggema et al., (2007) in sweet potato, however increasing the 2,4-D concentration let to reduction of callus number initiated. Raghavan (2004) also found existence of cell expansion and division activity during callus formation of cotyledone of
Arabidopsis due to 2,4-D application. In Bupleurum kaoi the highest callus weight was observed on half-strength MS medium containing lower concentration ( 0.1 to $0.2 \mathrm{mg} / \mathrm{l}-1$ ) of 2,4-D and increasing of its concentration did not further improve callus proliferation (Chen et al., 2005). The result gave evident that application of 2,4-D in anther cultured was still questionable.

Improvement of anthurium anther selected media via medium strength reduction. The study also revealed that though the experiment result was not as high as the previous study, but the WRM was still the most appropriate induction culture medium on callus induction compared to WM-D (Table 2). Improvement of them via reduction of their strength gave a significant effect on percentage of anther regeneration and number of callus formed, however there was no interaction response on both treatments. The result of the experiment also strengthened and gave evident that WRM kept being the most optimal medium on callus induction in anther culture of anthurium.

Interesting results were recorded on reduction medium strength in callus formation. The reduction influenced number of callus induced gradually and reached the highest effect on one eighth strength with $54 \%$ of anther growth, $29 \%$ anther regeneration and 1.8 number of callus produced per replication and then reduced till the zero strength. From the experiment it was revealed that the one eighth strength was the most suitable reduction of selected medium strength in obtaining high result and exhibiting significant different compared to others. The result gave evident that medium strength reduction stimulated high effect on callus 
Table 3. Effect of different medium strength of selected-media on callus initiation in anther culture of anthurium

\begin{tabular}{lccc}
\hline Medium strength & $\begin{array}{c}\text { Potential growth of } \\
\text { anther (\%) }\end{array}$ & $\begin{array}{c}\text { Percentage of anther } \\
\text { regeneration (\%) }\end{array}$ & Number of callus formed \\
\hline Full strength & $37.5 \mathrm{c}$ & $4.2 \mathrm{~b}$ & $0.3 \mathrm{~b}$ \\
Half strength & $42.7 \mathrm{bc}$ & $7.3 \mathrm{~b}$ & $0.4 \mathrm{a}$ \\
Quarter strength & $52.1 \mathrm{ab}$ & $11.5 \mathrm{~b}$ & $0.7 \mathrm{~b}$ \\
One eighth strength & $58.4 \mathrm{a}$ & $29.2 \mathrm{a}$ & $1.8 \mathrm{a}$ \\
One sixteenth strength & $54.2 \mathrm{ab}$ & $25.0 \mathrm{a}$ & $1.5 \mathrm{a}$ \\
Zero strength & $38.5 \mathrm{c}$ & $12.5 \mathrm{~b}$ & $0.8 \mathrm{~b}$ \\
Coefficient variation & 10.89 & 20.67 & 19.43 \\
\hline
\end{tabular}

Means followed by the same letter in the same column are not significant different based on Duncan Multiple Range Test (DMRT, $p=0.05$ )

formation in anther culture of anthurium as recorded by Hoque and Arima (2002) in Water Chestnut (Trapa Japonica Flerov), Chen et al., (2007) in vitro Bupleurum kaoi, Wang and Bao (2007) in pansy (Viola wittrockiana). Hoque and Arima (2002) reduced MS medium to half-strength supplemented with $2.7 \mathrm{mM} 2,4$ D, $108.0 \mathrm{mM}$ casein hydrolyzate, and $10.8 \mathrm{mM}$ phloroglucinol to support maximum callus induction. $A$ seventy-five percent primary callus induction rate was obtained from the explants cultured on half-strength MS medium containing $4 \mathrm{mg} / \mathrm{l}$ 2,4-D for 8 weeks in darkness (Chen et al., 2007). High callus induction of pansy was recorded on a half-strength MS medium supplemented with 0.45 mol l"1 2,4-d plus 8.9 mol l"1 BA (Wang \& Bao 2007). While totipotent calli of a Paphiopedilum hybrid (Paphiopedilum callosum 'Oakhi' $\times$ Paph. lawrenceanum 'Tradition') were easily induced from seedderived protocorms on a 1/2 strength Murashige-Skoog medium plus 1-10 mg l"1 2,4-dichlorophenoxyacetic acid (2,4-D) and 0.1-1 mg l"1 1-phenyl-3-(1.2.3-thiadiazol-5yl)urea (TDZ) (Lin et al., 2000).

The histological study of callus formation. Surprisingly result was observed in histological studies on callus formation derived from half anther cultured in the selected media. The study revealed that anther wall cells were actually the origin cells that grew and produced callus. Fifteen to twenty days after culture initiation the cells changed to be responsive and competent to medium components and exogenous plant growth regulators utilized in the selected media (Figure 1) as also reported by Nicuta et al., (2005) in anther culture of Brassica oleracea. The anther wall cells were then to become morphogenic and overcame dedifferentiation. Nucleus of cell moved from the edge to the center of cell. Nucleus size altered from small size to larger one and then divided actively from one nucleus to two nuclei, from two to four, four to eight simultaneously (Figure $2 \mathrm{E}-\mathrm{F}$ ) and finally the activity produced meristematic cells. The meristimatic cells divided continually in all direction and finally produced callus (Figure 3E-G). The callus derived from anther wall cells continued to grow and enlarge in shape, size and volume and clearly observed 2.0-3.0 months after culture initiation (Figure 3F-G).

It could also be reported that high morphogenic anther wall cells were determined from anther wall cells

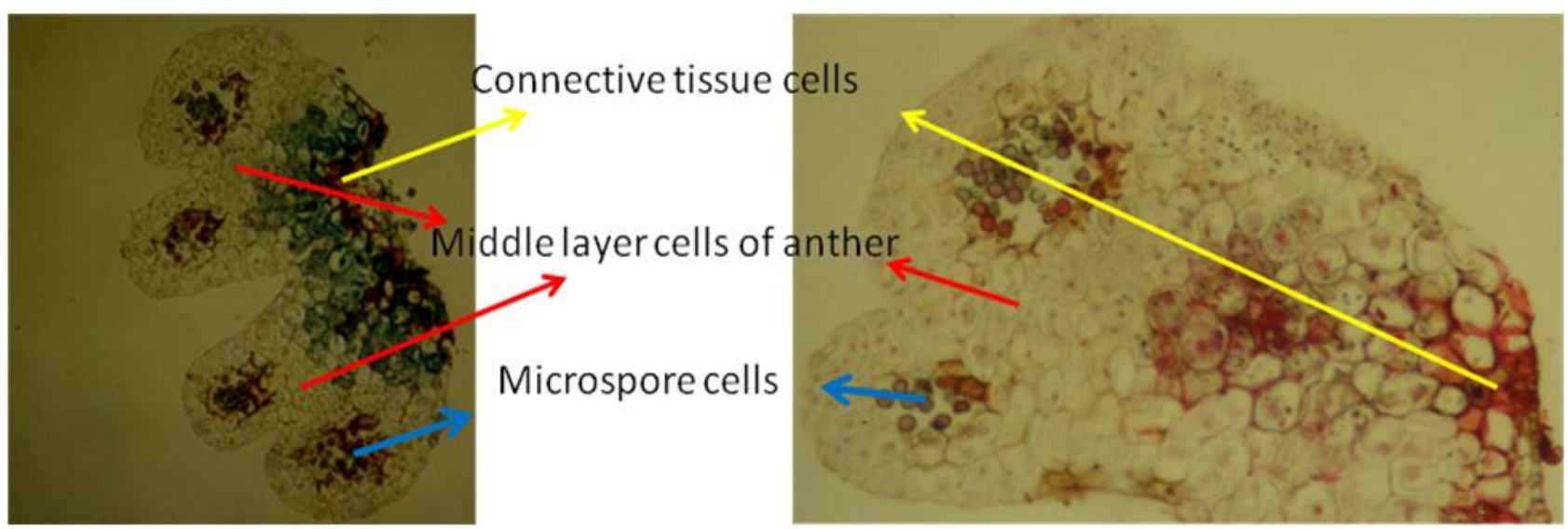

Figure 1. Different response of anther cells in androgenesis. Yellow arrows $=$ death cells of connective tissue, red arrows $=$ active 


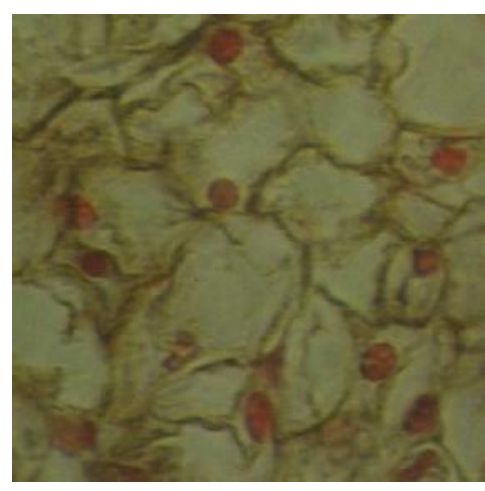

A

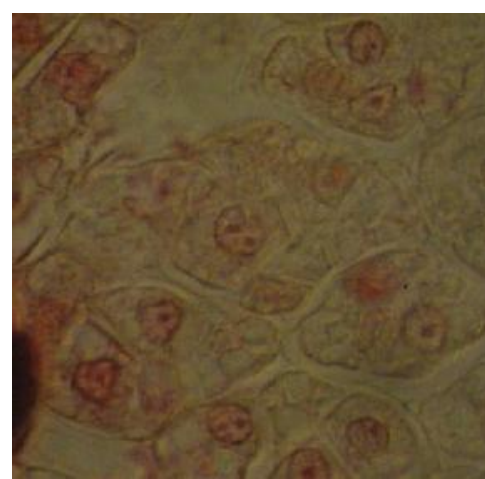

D

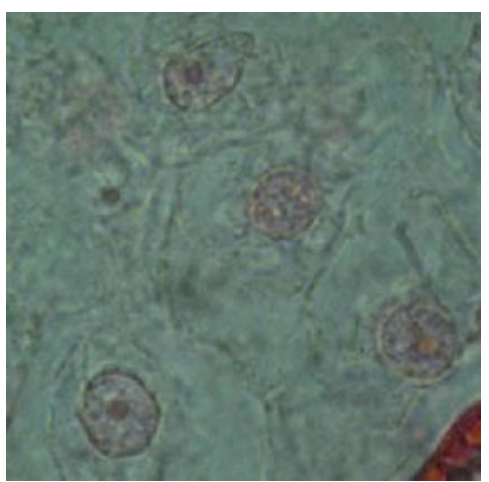

B

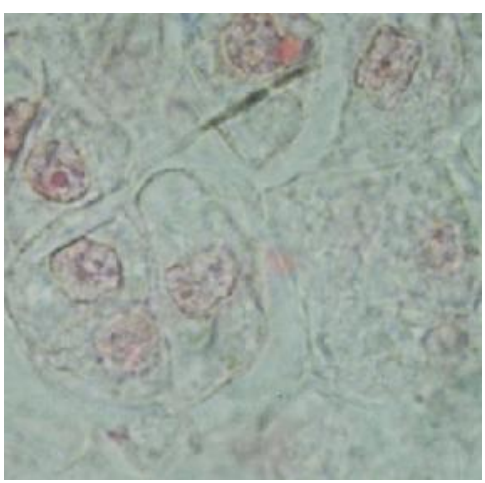

E

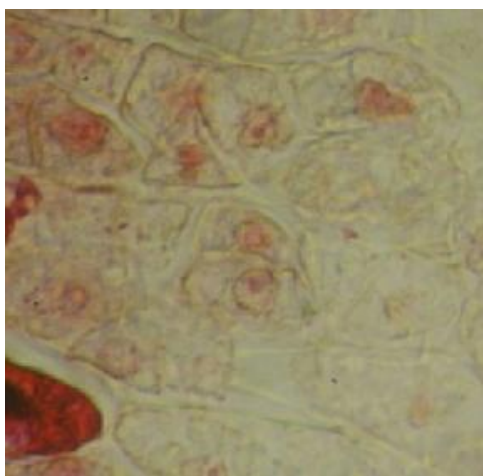

C

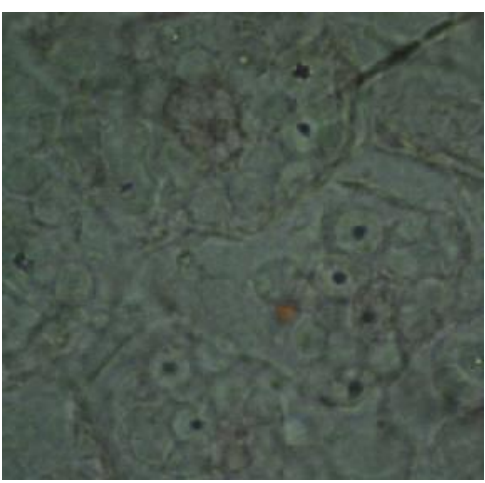

F

Figure 2. Dedifferentiation of middle layer cells of anther wall. A. Middle layer cells condition before dedifferentiation. B. Middle layer cells in initial dedifferentiation. C. One middle layer cell with two nuclei, D-E One middle layer cell with four nuclei, F. One middle layer cell with more than eigth nuclei

located between connective tissue and tapetum cells (indicated by yellow arrows in Figure 1 and red circles in figure $3 \mathrm{~A}-\mathrm{C}$ ). The active cells producing callus were derived from middle layer cells. In anther culture of rice, callus masses was originally regenerated from connective tissue (Maeda et al., 1978), while in anther culture of Vitis rupcstris, caullogenesis was regenerated from all anther tissue except endothecium (Altamura et al., 1992). In addition from four anther sacs containing microspore cells that were divided into two main parts (contain 2 sacs each) it was only one of main part that indicated high morphogenic response, produced callus and grew faster than another main part (Figure 3C-E). Growth direction was indicated by white arrows (Figure 3D-F).

From the study it was also well recognized that during callus formation microspore cells did not grow and do nothing. The cells kept and maintained in their position and existence from the early culture initiation till 2-3 months later (Figure 3A-F, green arrows). The condition was actually caused by morphogenic response of anther wall cells. The morphogenic response of anther wall and a few of connective tissue cells became the greatest obstacle in androgenesis of anthurium microspores as reported by Rodrigues et al., (2004) in soybean anther culture and a bit different situation was observed in connective tissue cells. The cells did not grow. A part of them was sprout out in different direction due to active growth of anther wall cells (Figure 3E-G).

Calli derived from half-anther culture continued to grow and produce shoots. After one to three times of explant sub-culture, initial apical meristem developing was observed (Figure $3 \mathrm{H}-\mathrm{I}$ ). In the stage meristimoid area consisting of densely cytoplasmic cells was formed. In the next step the initial apical meristem developing grew continually and produced initial shoots 4.5-6.0 months after culture initiation. The alteration was indicated by further growth of the meristimoid area for further cell division till arising small protrusions of tissue which gradually became green and organized into a growing point (Figure $3 \mathrm{~J}$ ). Finally the shoot bud development and its connective tissue were clearly observed (Figure 3K-I). Almost similar condition with different occurrence time was also recorded in lettuce (Murakami \& Oka 1996) \& Pothomorphe umbellate (Pereira et al., 2000). 


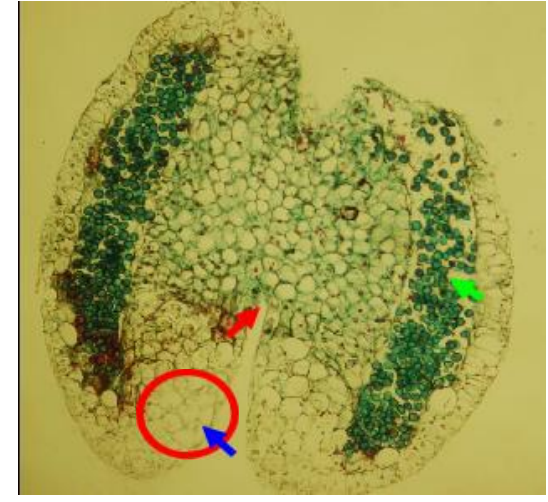

A

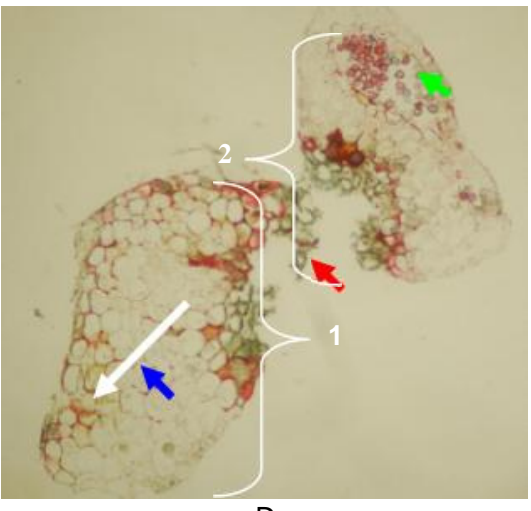

D

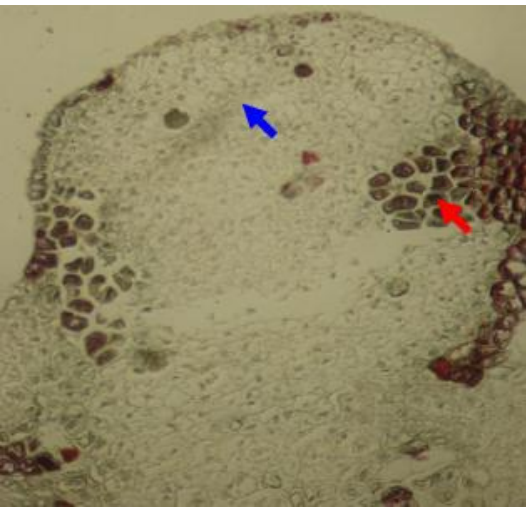

G

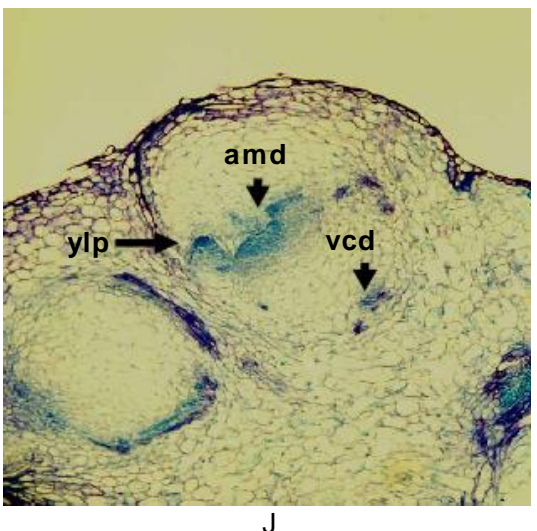

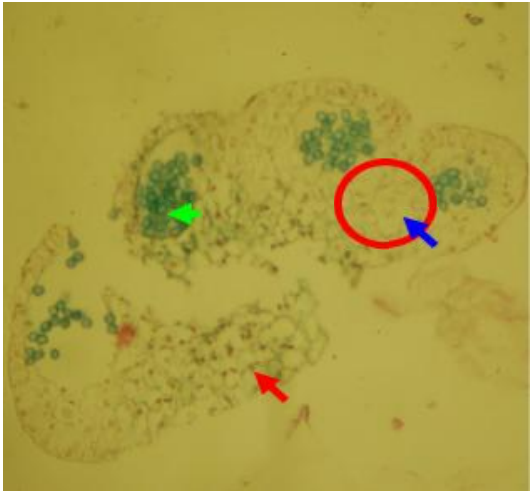

B

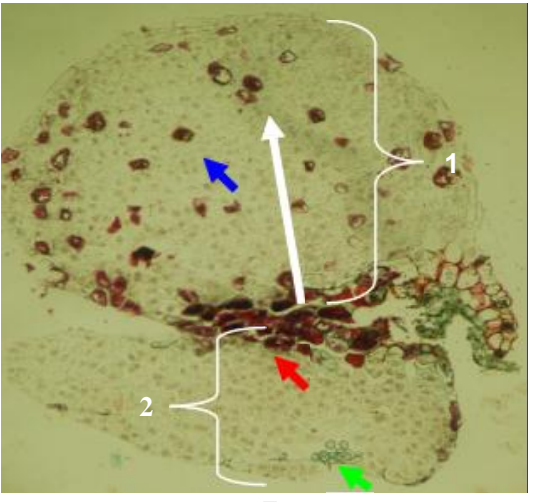

E

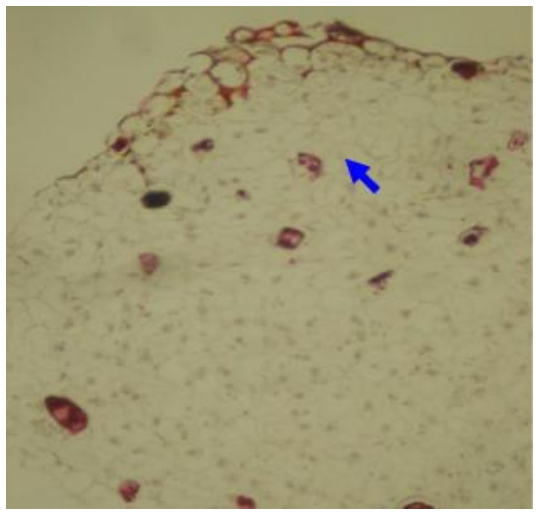

$\mathrm{H}$

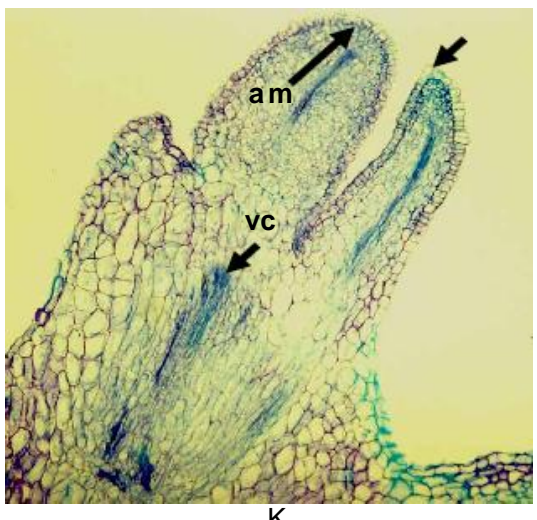

K

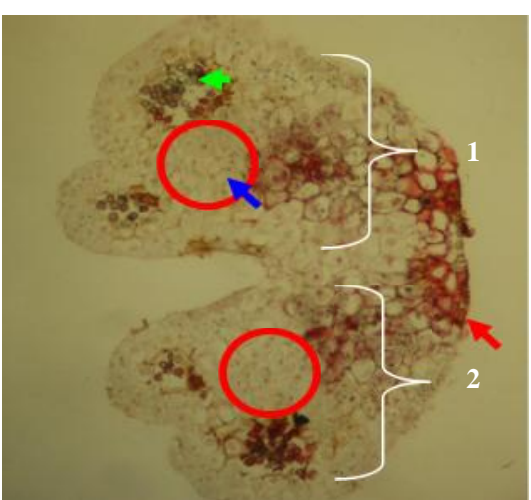

C
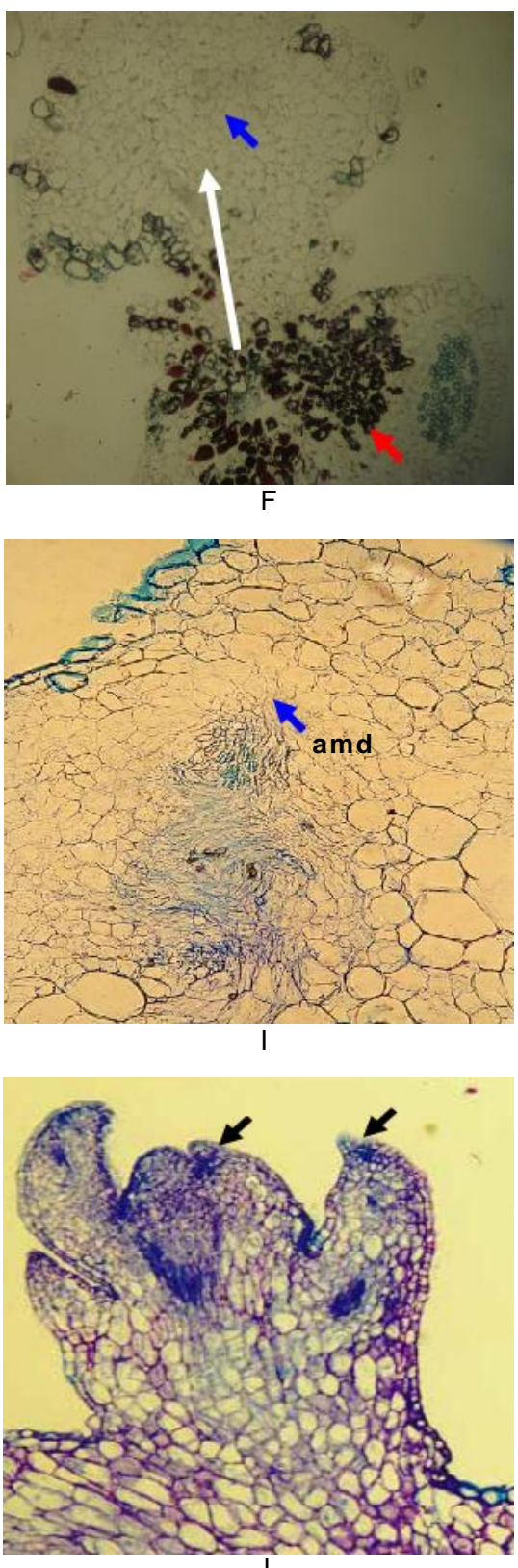

L

Figure 3. Histological studies of callus formation derived from anther till shoot initiation. A-longitudinal section of anther in initial culture, B-cross section of anther in initial culture, C-D - initial morphogenic response of anther $20-35$ days after culture initiation, F-G - regenerated and developed callus derived from anther 2.0-3.0 months after culture initiation, h-i-initial apical meristem developing 4.0-4.5 months after culture initiation, J-initial shoot developing 4.5-6.0 months after culture initiation. K-L developed shoots more than 6 months after culture initiation. Red arrows = connective tissue/cells, blue arrows = high morphogenic anther wall cells, green arrows $=$ microspore cells, amd - apical meristem developing, am - apical meristem, $\mathrm{vcd}$ - vascular cells developing, vc - vascular cells, ylp - young leaf primordia, yl - young leaf. Blue bars $=0.11 \mathrm{~mm}$, green bars $=0.28 \mathrm{~mm}$, red bars $=0.001 \mathrm{~mm}$ 


\section{CONCLUSION}

It can be concluded that the highest callus induction was clearly established in WRM. The medium stimulated potential growth of anther (PGA) up to $81 \%$ with $49 \%$ of percentage of anther regeneration (PAR) and 2.7 number of callus formed per replication (NCF). Significant improvement in callus formation was also recorded by reduction of medium strength of WRM to one eighth compared to others. The reduction induced PGA up to $58 \%$ with $29 \%$ of PAR and 1.8 NCF. From histological studies it was well recognized that regenerated callus on half anthers cultured on selected medium was originated from anther wall cells that were morphogenic in response to plant growth regulators and medium components. The morphogenic response of anther wall cells caused primarily on no androgenesis effect in microspore cells.

\section{ACKNOWLEDGMENTS}

I would like to express my grateful thank to the Indonesia Toray Science Foundation for the opportunity given to me in pursuing a 2008 Research Grant to carry out research in title: Several improvement treatments in anther culture of anthurium. I would like also to express my high appreciation to Fitri Rachmawati, Dewi Pramanik, Euis Rohayati, Supenti for their cooperation and helps during research activities conducted at tissue culture laboratory of Indonesian Ornamental Crops Research Institute.

\section{REFERENCES}

Ahmad, Z. 1993. A Study of The Chemical Manipulations Involved in The Clonal Propagation of Pistacia vera. Thesis. Institute of Chemistry University of the Punjab, Lahore.

Altamura, M.M., Cersosimo, A., Majoli, C. \& Crespan, M. 1992. Histological study of embryogenesis and organogenesis from anthers of Vitis rupcstris du Lot cultured in vitro. Protoplasma 171: 134-141.

Arzate-Fernandez, A.M., Nakzaki, H., Yamagata, H. \& Tanisaka. T. 1997. Production of double haploid plants from Lilium longiflorum Thunb. Anther culture. Plant Science. 123: 179-187.

Chen, U.C., Chueh, F.S., Hsia, C.N., Yeh, M.S. \& Tsay, H.S. 2005. Influence of 2,4-dichlorophenoxyacetic Acid on Leaf Callus Induction, proliferation and Saikosaponin Formation of in vitro Bupleurum kaoi Liu, Chao et Chuang. Crop, Environment \& Bioinformatics. 2: 39-49.

Eeckhaut, T., Werbrouck, S., Dendauw, J., van Bockstaele, E. \& Debergh, P. 2001. Induction of homozygous Spatiphyllum wallisii genotypes through gynogenesis. Plant Cell, Tissue and Organ Culture. 67: 181-189.

Han, D.S., Niimi, Y. \& Nakano, M. 1997. Regeneration of haploid plants from anther cultures of the Asiatic Irbid lily 'Connecticut King'. Plant Cell, Tissue and Organ Culture. 47: 153-158.
Hoque, A. \& Arima, S. 2002 .Overcoming Phenolic Accumulation during Callus Induction and In Vitro Organogenesis in Water Chestnut (Trapa Japonica Flerov). In Vitro Cellular and Development of Biology_Plant. 38: 342-346.

Hu, J.B., Liu, J., Yan, H.B. \& Xie, C.H. 2005. Histological observations of morphogenesis in petiole derived callus of Amorphophallus rivieri Durieu in vitro Plant Cell Reports. 24: 642-648.

Jabeen, N., Shawl, A.S., Dar, G.H., Jan, A. \& Sultan, P. 2006. Callus induction and organogenesis from explants of Avonitum heterophyllum-medicinal plant. Biotechnology. 5: 287-291.

Kumar, S. \& Kanwar, JK. 2007. Plant Regeneration from Cell Suspensions in Gerbera jamesonii Bolus. Journal of Fruit and Ornamental Plant Research. 15: 157-166.

Laukkanen, H., Häggman, H., Kontunen-Soppela, S. \& Hohtola, A. 1999. Tissue browning of in vitro cultures of Scots pine: Role of peroxidase and polyphenol oxidase. Physiolgia Plantarum. 106: 337-343.

Lin, Y.H., Chang, C. \& Chang, W.C. 2000. Plant regeneration from callus culture of a Paphiopedilum hybrid. Plant Cell, Tissue and Organ Culture. 62: 21-25.

Maeda, E., Villalobos, V.M. \& Sugiura, T. 1978. Fine structure of the regenerating cells in Fragaria anther cultures. Japan Journal of Breeding. 28: 143-146.

Mandal, N. \& Gupta, S. 1996. Studies on histomorphological course of events during androgenesis of rice (Oryza sativa L.) Phytomorphology. 46: 99-107.

Marshall, M.R., Kim, J. \& Weim C.I. 2000. Enzymatic Browning in Fruits, Vegetables and Seafoods. www.fao.com/browning explant/Enzymatic Browning.html. (16 September 2009).

Mello, M.O., Mello, M. \& Appezzato-da-Glória, B. 2001. Histological analysis of the callogenesis and organogenesis from root segments of Curcuma zedoaria Roscoe. Brazilian Archives of Biology and Technology. 44: 197-203.

Mishiba, K., Okamotom T. \& Mii, M. 2001. Increasing ploidy level in cell suspension cultures of Doritaenopsis by exogenous application of 2,4-dichlorophenoxyacetic acid. Physiologia Plantarum. 112: 142-148.

Mohan-Jain, S. \& Bhalla-Sarin, N. 1996. Haploidy in Petunia. In: In Vitro Haploid Production in Higher Plants. Mohan Jain, S., S.K. Sopory and R.E. Veileux (Eds). Kluwer Academic Publishers. Dordrecht/Boston/London. 5: 53-71.

Nakano, H. \& Maeda, M. 1989. Cyto histological studies on callus formation and its regeneration in anther culture of Oryza sativa L. Japan Journal of Crop Science. 58: 409418.

Nicuta, N.D., Toma, I.N. \& Ghiorghi, G.I. 2005. Morphogenetical and histological studies of "In Vitro" anther cultures of Brassica Oleracea L. Genetică şi Biologie Moleculară. TOM V: $111-118$.

Oggema, J.N., Kinyua, M.G. \& Ouma, J.P. 2007. Optimum 2,4$D$ concentration suitable for embryogenic callus induction in local Kenyan sweet potato cultivars. Sian Journal of Plant Sciences. 6: 484-489.

Ozyigit II, Kahraman MV, Ercan O. 2007. Relation between explant age, total phenols and regeneration response of tissue cultured cotton (Gossypium hirsutum L.). African Journal of Biotechnology. 6: 3-8.

Pedroso, M.C. \& Pais, M.S. 1996. Anther and microspore culture in Camellia japonica. In: In Vitro Haploid Production in Higher Plants. Mohan-Jain, S., Sopory, S.K. \& Veileux, R.E. (Eds.). Kluwer Academic Publishers. Dordrecht/Boston/London. 5: 89-108.

Pereira, A.M.S., Bertoni, B.W., Appezzato-da-Gloria, B., Araujo, A.R.B., Januario, A.H., Lourenco, M.V. \& Franca, S.C. 2000. Micropropagation of Pothomorphe umbellate via direct organogenesis from leaf explants. Plant Cell, Tissue and Organ Culture. 60: 47-53.

Rachmawati, F. 2005. Kultur Anther pada Anthurium (Anthurium andreanum Linden ex André). Thesis. Departemen Agronomi and Hortikultura. Fakultas Pertanian. Institut Pertanian Bogor. 
Raghavan, V. 2004. Role of 2,4-dichlorophenoxyacetic acid (2,4 d) in somatic embryogenesis on cultured zygotic embryos of arabidopsis: cell expansion, cell cycling, and morphogenesis during continuous exposure of embryos to 2,4-d. American Journal of Botany. 91: 1743-1756.

Rodrigues, L.R., de C. Forte, B., Oliveira, J.M.S., Mariath, J.E.A. \& Bodanese-Zanettini, M.H. 2004. Effects of light conditions and 2,4-D concentration in soybean anther culture. Plant Growth Regulation. 44: 125-131.

Saji, K.V. \& Sujatha, M. 1998. Embryogenesis and plant regeneration in anther culture of sunflower (Helianthus anuus L.) Euphytica. 103: 1-7. 